\title{
АРХІТЕКТОНІКА ОНІРИЗМУ В РОМАНІ ОЛЕСЯ ІЛЬЧЕНКА МІСТО 3 ХИМЕРАМИ
}

\author{
ЮЛІЯ ДРАГОЙЛОВИЧ \\ Белградський університет, Белград — Республіка Сербія \\ julybil@ukr.net; ORCID: 0000-0001-6948-1402
}

\section{ARCHITEKTONIKA ONIRYZMU W POWIEŚCI OŁESIA ILCZENKI МІСТО 3 ХИМЕРАМИ}

\author{
JULIJA DRAGOJLOVIĆ \\ Uniwersytet w Belgradzie, Belgrad — Republika Serbii
}

\begin{abstract}
STRESZCZENIE. W artykule przedstawiono wyniki badań nad właściwościami literackiego sposobu kształtowania elementów onirycznych w powieści Ołesia Ilczenki Miсто з химерами (2009), co unaocznia aktualność niniejszego studium naukowego. Narracja skupiona jest wokół niezwykłej postaci wybitnego architekta Władysława Horodeckiego. Tak sformułowane zadanie wymagało przeprowadzenia odpowiednich kroków badawczych, tj. wyszukania fragmentów onirycznych $\mathrm{w}$ tekście oraz określenia ich specyfiki narracyjnej i wartości funkcjonalnej $\mathrm{w}$ terminologii krytyki onirycznej. Zagadnienie oniryzmu w twórczości O. Ilczenki nie było dotąd opisane w literaturoznawstwie ukraińskim, dlatego podjęte badanie można uznać za nowatorskie. Podsumowując wyniki analizy, zauważamy, że w powieści występują fragmenty snów, fantazje senne, zminimalizowane zapisy snów, a także wiele przerywanych „komunikatów” o tym, że niektórym bohaterom śnią się pewne sny, głównie koszmary. Przedstawiając poszczególne stany oniryczne, pisarz wybiera technikę narracyjną swoistego sczytywania snów z (pod)świadomości bohaterów przez niediegetycznego narratora. Sny i marzenia W. Horodeckiego ujawniają stan psychologiczny wewnętrznej walki, czasami stają się wizjami proroczymi, które wpływają na bieg wydarzeń, ale na ogół pełnią funkcję środków kompozycyjnych, wzmocnienia mistycznego modusu tekstu, tworzenia fragmentu „mitu kijowskiego”.
\end{abstract}

Słowa kluczowe: oniryzm, sen literacki, fantazje senne, marzenia, mistyczny modus tekstu, narracja 


\title{
ONEIRISM ARCHITECTONICS IN OLES ILCHENKO'S NOVEL MISTO Z KHYMERAMY
}

\author{
YULIYA DRAGOJLOVIC \\ University of Belgrade, Belgrade — Republic of Serbia
}

\begin{abstract}
The present article analyses the methods of the artistic shaping of oneiric elements in Oles Ilchenko's novel Misto z khymeramy (2009). The novel narrates the story of Vladislav Gorodetsky, an extraordinary personality and a famous architect. The goal of the study is to identify the oneiric fragments in the text, and define their narrative peculiarities and functional load using oneiric terminology. Ilchenko's oneirisms have still not received enough attention in the Ukrainian literary criticism, which proves the topicality of our research. Summarizing the results of the analysis, we note that the novel includes the fragments of dreams, sleepy fantasy, minimized delirium records, as well as many pieces of 'encrypted' information about the fact that certain characters have certain dreams, mostly nightmares. When describing the above oneiric states, the author chooses a narrative technique of dreams reading by a non-diegetic narrator from the (sub)consciousness of characters. Gorodetsky's dreams and visions imply his psychological status, internal struggle, sometimes they contain prophecies which influence the course of the story. In general, his dreams and visions are the main compositional elements that serve the functions of the intensification of the mystical modus of the text and the creation of the fragment of "Kyiv myth".
\end{abstract}

Key words: oneirism, literary dream, sleepy fantasy, delirium, narrative

P

оман Місто з химерами (2009) — це перша “зріла” прозова книга О. Ільченка, не враховуючи тих, що написані для дитячої та підліткової аудиторій. О. Ільченко - сучасний поет, прозаїк, сценарист, киянин і знавець історії архітектури Києва. Оповідь роману центрується навколо постаті видатного архітектора Лешка Дезидерія Владислава Городецького (1863-1930), “київського Гауді” польського походження, перипетії долі й архітектурні творіння якого не припиняють привертати увагу широкої громадськості.

„Трохи детективного, трохи документального, трохи містичного й актуального та зрозумілого більшості читачів суспільно-політичного", - так літературознавець І. Котик у своїй рецензії Геометрія української химерності визначає складники рецепту популярного прозового письма й визнає, що книга О. Ільченка написана „майже за цим рецептом““ [Котик 2011: 114]. Наслідком цього й стала здобута нею перемога на літературному конкурсі журналу Кореспондент. Справді, у романі Місто з химерами виразно акцентовані детективний, документальний та містичний дискурси. У детективній лінії зафіксовано пошуки й дослідження двох персонажів підліткового віку Владислава та Артема, які розшифровують певні моменти із життя В. Городецького: чому архітектор спорудив Національний музей у формі літери L; 
чому на його будинку на Банковій, 10 розмістився страшний скульптурний зоопарк; де заховано папку з його кресленнями, що означає трикутник, який він зобразив на одному аркуші. Документальну основу художнього тексту засвідчено в розміщеному тут фрагменті паратекстуального оформлення авторській подяці С. Кілессо та Д. Малакову за надані ними унікальні архівні матеріали, де відтворено події першої третини XX ст., зокрема й факти із життя В. Городецького [див.: Ільченко 2009: 3]. У своїх інтерв’ю О. Ільченко зазначає, що його героя оточує безліч достовірних дрібниць, що „в романі всі імена, назви вулиць, адреси, навіть той факт, що на будівництві костелу загинув робітник — це все правда" [Клименко 2008]. У творі інструментом проникнення у сферу містичного, що пов'язана із загадкою рівнобічного трикутника, $є$ нав'язливі сни та марення й головного персонажа, i деяких побіжних персонажів. Якщо актуальність описаного в романі простежується в окремих штрихах і деталях київського сьогодення, то суспільно-політичний складник тут досить невиразний. Напевно, саме він $\epsilon$ причиною “майже відповідності" рецепту, наведеному дослідником І. Котиком. Водночас цей літературознавець констатує, що твір Місто з химерами виходить за рамки літературної практики, яку зазвичай таврують “масовим чтивом”, адже в ньому захоплює глибинна проблема - прагнення зрозуміти суть мистецької діяльності й зв' язку мистецтва 3 дійсністю [Котик 2011: 115]. Уважаємо, що із зазначених вище “інгредієнтів" популярної літератури саме містичний дискурс, а точніше його оніричне підгрунтя, дає змогу репрезентувати авторський варіант інтерпретації таїни архітектурних творінь В. Городецького.

Мета цього дослідження полягає у виявленні оніричних фрагментів романного тексту й визначенні їхньої наративної специфіки та функціонального навантаження. Цей аспект ще не отримав належного висвітлення, хоча вихід Міста з химерами, безперечно, додав популярності О. Ільченку. Так, дослідженню творчості письменника приділяють увагу відомі літературознавці, зокрема такі, як Ю. Джугастрянська, І. Котик, К. Москалець, Я. Поліщук, Л. Таран).

Звертаючись до художнього зображення сну, а також інших холотропних станів героїв (марень, галюцинацій, божевілля, сомнамбулізму, візіонерства, екстазу та ін.), що зараховуються до оніропростору, митці різних епох передусім прагнуть оприлюднити сферу несвідомого, адже в оніропросторі літературного твору „зміст колективного несвідомого стає досяжним для свідомого переживання" [Гроф 1997: 25]. Оскільки світова література сповнена прикладів репрезентування оніричного простору, не дивно, що ця тонка сфера людської психіки захоплює багатьох літературознавців, зокрема й українських, особливо тих, які зосереджують фокус уваги на художніх зразках сюрреалізму й постмодернізму тощо. Як зауважує Т. Бовсунівська, „онірокритика є містерією літературознавства і як містерія має специфіку доторкання до архетипу, 
що [...] й забезпечує «реальність» нашого оніричного досвіду” [Бовсунівська 2004: 16]. Як і кожна аналітична стратегія літературознавства, онірокритика має певну термінологічну й поняттєво-категорійну базу, проте ії теорія не $\epsilon$ уніфікованою з відповідним комплексом методологічних підходів до дослідження холотропних станів героїв за літературними текстами як художніми свідченнями існування ірреального.

У найширшому розумінні звернення письменника до сну є літературним прийомом. Літературний сон — це одиниця у структурі твору й певна художня стилізація природних сновидінь, це "явне сновидіння", “текст сновидіння" [Шупта-В'язовська 2004: 162]. Порівняно з природним сном він $є$ псевдосном, оскільки його конструює й контролює авторська свідомість, тоді як насправді свідомість у цьому стані, навпаки, “пригасає”. Художній сон — своєрідне “семіотичне вікно", точніше семіотична форма реалізування авторської інтенції. Це не просто результат фантазії автора, а своєрідне "зашифроване послання" митця читачеві. Вибір образної символіки сновидіння, сюжету, персонажів, яким він делегований, - усе це вияв авторської інтенції в оніричному просторі тексту, що поряд з іншими текстовими одиницями “працює” на певну авторську ідею [Шупта-В'язовська 2004: 162].

Підкреслення автором важливості ролі оніропростору в романі Micmo 3 химерами можна зрозуміти вже 3 перших сторінок тексту, адже твір починається саме з опису змісту сну головного персонажа Владислава Городецького: хлопчик і дівчинка вінчаються в католицькому храмі, з якого потім їх виганяє ксьондз. Тут же в наративі всезнаючого автора міститься натяк на те, що це повторюваний сон, на втому архітектора, спричинену різними сновидіннями, на тонку межу між оніричним і реальним, яка проходить у свідомості героя (прокинувшись від цього сну-потрясіння ${ }^{1}$, він деякий час не може збагнути, де насправді знаходиться), а зокрема і на пролептичний характер цього оніричного фрагмента: Небезпека, невидима іншими, навіть близькими людьми, присунулася до нього впритул - Городеиький гостро відчував ие [Ільченко 2009: 6]. Далі за текстом автор дублює вже репрезентований сон, який відкриває текст роману, через згадку, що дружині Городецького Корнелії снилося двоє дітей, яких виганяли із храму, наче з раю. Порівняно із сюжетом першого сну цей оніричний сюжет дещо продовжений: у хлопчика випав зуб, що дало змогу Корнелії впевнено трактувати цей сон як передбачення лиха:

\footnotetext{
${ }^{1}$ Примітка. Існує немало класифікацій літературних снів та різних холотропних станів. Характеризуючи "снозаписи“" у романі Мicmo з химерами, ми опиралися на терміносистему, яку використовує Н. Фенько, що пропонує за видами станів сну в художньому зображенні виділяти картини власне сновидінь, сонні фантазії, марення, видіння, сни наяву; за характером впливу на психологію героїв - сни-потрясіння, що поділяються на сни асихологічного конфлікту (сон-катарсис, сон-каяття) та пророчі сни, і сни-заспокоєння (сни-мрії, сни-спогади, сон-архетип) [Фенько 1999: 9-11].
} 
Вона знала, що хтось має померти, й відтак ие нещастя торкнеться їх обох [Ільченко 2009: 13]. Композиційно таке оніричне “знання” Корнелії подається вже постфактум. Між описами сну Городецького і його дублетного варіанта, що снився Корнелії, оповідається про будівництво католицького костелу на Великій Васильківській, де загинув робітник, начебто через недбалість архітектора Городецького. Отже, уже перший оніричний фрагмент твору створює ефект тривожного очікування майбутніх подій, а завдяки зазначеному вище способу дублювання сну цей ефект посилюється, відповідно налаштовує читача на довіру до сновидінь як до повноцінних фрагментів нарації, не менш важливих, ніж інші складники художньої реальності, які можна пояснити законами логосу.

Навіщо ж автору залучати “леткі” й непевні “матерії” оніризму в оповідь про знаного київського будівничого Городецького? Можливо, тому, що, незважаючи на всі архівні матеріали, сам образ архітектора, його біографія й архітектурні творіння оповиті загадковістю й непевністю, і внаслідок поєднання цих "мінуса" й "мінуса" якимось чином усе-таки отримуємо “плюс"? 3 постаттю В. Городецького пов'язані численні “чому?”, на які ні його сучасники, ні нинішні дослідники не мають єдиноприйнятної відповіді. О. Ільченко вдало демонструє знання життєпису цього архітектора, але не обмежує наповнення тексту біографічними відомостями. Він зазначає: „В мене як у автора є своя версія життя Городецького - i чому він поїхав до Персії на схилі літ, адже йому і в Польщі чудово жилося, і чому побудував цей Будинок із химерами [...]" [Клименко 2008]. Відтак у романі В. Городецький зображений як досить неординарна людина 3 нестандартним поєднанням уподобань та зацікавлень - елегантний і вишуканий, екзотичний і епатажний чоловік (ходив київськими вулицями в крагах, шкірянці й з мавпочкою на плечі), улюбленець жінок (але вірний дружині), вправний автомобіліст (мав перше в Києві приватне авто), чудовий стрілець (неодноразово здобував перемоги на стрілецьких змаганнях), затятий мисливець (здійснив мисливські експедиції на Алтай і в Африку, написав книгу $B$ джунглях Африки), модельєр взуття й костюмів для акторів, архітектор. Його Будинок 3 химерами, що став київським дивом, об'єктом пліток, чуток, різних неймовірних оповідок [Ільченко 2009: 45] - найзагадковіша споруда епохи модерну в Києві. Трактування містерії ії появи автор подає спершу через діалог архітектора 3 дружиною Корнелією: То було парі! [...] Я побився об заклад, щзо за два роки на дикому косогорі, зовсім непристосованому до будівництва, зведу диво! I я ие зробив! [Ільченко 2009: 23]. Корнелію ж мучить те, що інтер'єр будинку, у якому мешкає їхня сім'я, прикрашають ящірки, крокодили, змії! і не просто якісь вужі чи гадюки, а оті мало не біблійні гади, спокусники роду людського! [Ільченко 2009: 24]. Хоча свій ідейний задум скульптурного зоопарку, який прикрашає їхню будівлю, В. Городецький тут називає жартом, грою фантазії, для Корнелії це звучить 
непереконливо. Будинок 3 химерами видається таємницею, ніби приховує щось важливе, сокровенне. Пошуки відповідей О. Ільченко спрямовує в оніропростір.

Пристрасть до полювання давала В. Городецькому можливість відчувати себе володарем часу $і$ життя - не тільки приречених під його влучними пострілами тварин - а й власного життя, але так само гостро архітектор відчував і залежність від незримих, одначе потужних сил, які керували ним, вели його [...]. Куди? Він прагнув мати відповідь на ие питання [Ільченко 2009: 21]. Полювання для нього було розвагою, але ціною такої розваги були нав'язливі сни та марення. В. Городецькому сняться дивні химерні сни, що впливають на його волю, а відтак і на оформлення славнозвісного будинку. До такого висновку дійшли двоє персонажів-підлітків Артем та Влад, які в сучасному часовому зрізі досліджують архівні матеріали. Вони вважають досить хиткою версію пояснення химерного оздоблення будинку, відповідно до якої мовбито він у такий спосіб хотів розрекламувати можливості цементу й бетону, що виробляв його завод.

Основним образом, що з'являється в цих видивах-кошмарах, є Змій, який навіює йому свої думки, бажає, щоб він підкорявся та виконував його накази, і заперечити Змію неможливо, оскільки жодна світська людина неспроможна опиратися волі Темряви [Ільченко 2009: 27]. У наративній структурі твору сон про Змія вперше фіксується як фрагмент, що приходить на зміну спогадам про полювання на півдні Туркестанського краю, у які В. Городецький поринув, лягаючи спати. Утім, О. Ільченко тут використовує техніку монологічного переповідання сну всезнаючим наратором, який позиціонується поза дієгезисом (наче наратор зчитує сни героя), унаслідок більш виразно акцентується текстуальна природа цього літературного сну, тобто псевдосну. Змій має колосальні плани - установити свою владу над Києвом, відтак нейтралізувати сакральне призначення древнього міста: Змій воліє, щзоб архітектор продовжив творити власне Змієве Місто, яке з давніх-давен належало Йому, його поріддю [...]. Змій незнищенний, йому і досі належать незліченні, неміряні ходи, нори, печери, підземні лабіринти Вічного Міста над Дніпром. і скільки б не називали те Місто святим, одухотвореним, «Срусалимом землі Руської», однак - воно належало і належатиме 3мієві! [Ільченко 2009: 27]. У цьому “снозаписі” відбувається й своєрідний аналіз, принаймні встановлення ланцюгового зв'язку між волею Змія, будівництвом київської каналізації й збагаченням архітектора, який його проводив і який тепер може витрачати гроші на улюблену забавку — полювання, а також констатація того, що частину задуму великого Змія відтак він уже знає! [Ільченко 2009: 29]. Аналіз, зокрема й самоаналіз, продовжується після пробудження: міська каналізація побудована на користь місту й людям чи на користь силам темряви (як “промовляла" його підсвідомість в оніропросторі); гроші для нього не мета, а засіб, і полювання - це ж не вбивство, 
чи панові архітекторові насправді властиві пристрасть до золота й крові, тому він підкоряється волі потвори (як каже Змій у сні, а отже, підсвідомість видає непевність в істинних намірах зодчого). О. Грищенко, один 3 дослідників творчості О. Ільченка, зазначає: „Символічний підтекст, що вкладається у структуру роману, веде до традиційного в літературі розігрування конфлікту добра й зла" [Грищенко 2014: 58]. Уважаємо за потрібне уточнити, що конфлікт добра й зла, за художньою версією письменника, розгортається саме в підсвідомості головного персонажа, а перемістити його на рівень свідомості вдається за допомогою прийому оніризації. Так читач спостерігає картину існування героя на межі реального та ірреального світів.

За концепцією К.-Г. Юнга, головним розмежуванням між сном та міфом $\epsilon$ свідоме оброблення архетипів у міфі та несвідоме їхнє використання вві сні [Бовсунівська 2004: 16]. Але в літературному сновидінні архетипи слугують особливо сприятливим підгрунтям для індивідуального міфотворення. Отже, автор недаремно використовує прадавній архетип Змія в романному оніропросторі. Демонізований Змій в інтенсіональному контексті згаданого вище сновидіння $є$ латентним противником героя, провокатором його "внутрішнього зла"2. До найдавніших уявлень про Змія належить його ототожнення 3 відкритими й підземними водоймами, відтак він контролює сили води. Давні слов'яни вірили, що Змій як істота нижніх вод живе на межі Яви (матеріального, видимого світу) й Нави (нематеріального, потойбічного), проникаючи і туди, і сюди [Борцов 2018]. У творі О. Ільченка відстежуємо прямий натяк: архітектор будував каналізацію (ще до того, як став відомим творцем будівель, зокрема кенаси для громади кераїмів, Національного музею старовини й мистецтв, Будинку актора, Миколаївського костелу, Будинку 3 химерами) саме 3 волі Змія, але не усвідомлював цього. У тексті роману неодноразово використані евфемізми “той із снів”, “гість із снів”, “прибулець із снів”, чим акцентується увага на оніричній природі діалогу з підсвідомими структурами.

Згаданий вище “снозапис" про Змія та спроба його проаналізувати В. Городецьким (який, зокрема, стурбований, оскільки ця потвора стала частим гостем його снів), свідчать про те, що оніропростір є репрезентантом підсві-

\footnotetext{
${ }^{2}$ Примітка. Відштовхуючись від цього твердження, можна вважати, що автор роману актуалізує негативний потенціал цього первинного образу. Усі образи божеств у формі змія обов'язково мають хтонічну природу, що свідчить про спорідненість цього архетипу із Сатаною. В архаїчних міфологіях Змій $є$ втіленням ідеї поєднання неба й землі, тому він двоїстий за своєю природою (і небезпечний, і благочинний). У наступних “розвинених" міфологічних системах переважає його негативна роль, спостерігається демонізування демонотеїстичних божеств. Імовірно, архетип Змія як більш ранній формує архетип Сатани як більш “об'ємного” [Борцов 2018]. На нашу думку, архетип Змія як елемент авторського міфотворення — один з найбільш цікавих аспектів у цьому романі, що потребує окремого, глибшого дослідження.
} 
домого героя, його внутрішньої боротьби, природних потягів та бажань. Сни стають своєрідним містком між зовнішнім на внутрішнім світами, власним “Я” та довкіллям, свідомістю й підсвідомістю. Аналітичні роздуми В. Городецького завершуються висновком: треба ошукати темряву $i$ заспокоїти свій дух, спробувати пограти з нічними потворами, які б вони не були - уявні чи справжні. Грати - й перемогти! [Ільченко 2009: 32]. У чому полягає суть гри як способу звільнення від марень і кошмарів, дізнаємося вже на останніх сторінках роману, коли логічно складається пазл з різних фрагментів оповіді. Але в тексті простежуємо алюзії стосовно того, що ця гра пов'язана 3 основною діяльністю В. Городецького, тобто торкається його архітектурних творінь. Основне питання, що постає перед старшокласниками Владом та Артемом під час дослідження його життєпису, — “що хотів висловити зодчий своїми спорудами?”.

Архітектурну містерію розташування трьох знакових споруд на карті Києва спочатку розгадує В. Городецький (маючи страшну підозру, навіяну снами), а потім і друзі-підлітки. Будинок з химерами В. Городецького (Банкова, 10), будинок з головою горгулії М. Бобрусова (Велика Житомирська, 8) і будинок 3 котами В. Безсмертного (Гоголівська, 23) прикрашені химерними істотами. Трикутний зв'язок між ними символічний. Виявляється, що в центрі рівнобічного трикутника, який вони утворюють, свята Софія Київська. Вона позначена на знайденій хлопцями схемі В. Городецького як абревіатура ССК, що можна розшифрувати і як Сакральне Серце Києва (повідомляють персонажі XXI ст.). Інакше кажучи, Софійський собор оточений трикутником чортовиння, i ці архітектурні пам'ятки „стають своєрідною зоною контакту навзаєм антагоністичних сил" [Поліщук 2011: 11]. Про символічний трикутник новостворених споруд здогадався й архітектор В. Безсмертний, чим і поділився в розмові 3 колегою В. Городецьким: Трикутник. Я теж усвідомив його існування, проте лише після зведення свого "Будинку з котами”, співвіднісши його з вашим “Будинком із химерами”, з “Будинком із диявольською головою”. Виходить, що $i$ я, $i$ ви, і Бобрусов мусили підкоритися йому [Ільченко 2009: 122]. У цьому діалозі архітекторів немає згадок про “деякі дивні сни”, але в розмові із ще одним співтворцем цього трикутника, колегою М. Бобрусовим, що відбулася раніше, В. Городецький дізнається, що і йому воно з'являється то у вигляд $i$ якогось Змія Горинича, то просто як величезний змій чи дракон [Ільченко 2009: 98]. Головний герой усвідомлює, що його Будинок з химерами став компромісом між простою чудасією мисливия й натхненно-страшним витвором майстра, який не зі своєї волі побудував престол для Нього [Ільченко 2009: 49], так само й інші два архітектори роблять висновок,

${ }^{3}$ Примітка. Ідею стосовно того, що химерні творчі результати архітектора нав'язані силами потойбіччя, підтверджено словами, які автор приписує Лесі Українці: Не пана Городеиького вина в тому, що він спорудив отакий будинок. [...] То його тягар, нездоланний примус. [...] Він не хитається, а пручається, бореться із якоюсь силою... Біжить від думки своєї ж... 
що піддалися навіюванням сил зла. Образ Змія втілює підступність та бажання володіти Києвом. Заважають тільки храми на цих горах. Так, не люди, а храми. Надто багато таких споруд з'явилося за останню тисячу років [Ільченко 2009: 28]. Храм - це святе місце, оберіг, що захищає людей від темних сил. Результат дії трикутника очевидний з позиції сучасних спостерігачів Влада та Артема: храм припинив функціювати як сакральний об'єкт, його перетворено на музей, у країні відбуваються глибинні соціальні й політичні зрушення з негативними наслідками. Сон про вигнання із храму, що сниться й В. Городецькому, і його дружині, яким, власне, починається текст роману, може вказувати на незахищеність героїв перед силами зла.

Отже, роман Місто з химерами можна розглядати як фрагмент "київського міфу”, тобто міфічний складник “київського тексту”. В основі індивідуального авторського міфотворення - вплив ірраціонального, потойбічного на урбаністичний простір Києва, у репрезентації якого велику роль відведено оніризму. Фактично всіх героїв, причетних до загадки архітектурного трикутника або до іії розгадування, пов'язує те, що вони бачать уві сні образ Змія. Напр., старшокласнику Владові в певний момент починають снитися і Змій, i В. Городецький, якийсь ключ, якась скринька тощо. Утім, у тексті не подано описів цих сновидінь, є тільки констатація такого факту, що має на меті увиразнити духовний зв'язок між архітектором і юним дослідником. Фактично більшість “снозаписів" ущільнюються до самого факту сну, без викладу його змісту.

Сон про Змія, який нав'язує свою волю, сниться В. Городецькому багато разів. Основні функції таких повторень цього факту в романній оповіді показати психологічний тягар, що гнітить героя, а також підтримувати в реципієнта той містичний настрій, який наратор послідовно навіює із самого початку твору. Архітектор немов постійно конфліктує зі своїми страшними снами, намагається їх побороти. Оніропростір вступає в діалог з дійсністю, навіть диктує себе дійсності. Наратор констатує: Що більше непевність стосовно майбутнього розливалася в суспільстві, то рідше приходили в його (архітектора - прим. Ю. Д.) сни небажані гості [Ільченко 2009: 86]. Отже, коли суспільна реальність ставала жахливішою (революція, Перша світова війна, громадянська війна), В. Городецькому припиняли снитися саме кошмари.

Цікаво, що в архітектоніці оніризму, представленого в цьому романі, найбільш об'ємним оніричним фрагментом є не сон, а сонна фантазія архітектора,

[Ільченко 2009: 46-47]. Уводячи в оповідь представників київського творчого бомонду поч. XX ст., О. Ільченко роль такого “свідка" відводить саме Лесі (Ларисі Петрівні Косач) як особливо чуттєвій натурі, здатній сприймати тонкощі людської психіки й бачити більше, ніж те, що є видимим. 
тобто своєрідна гра його уяви на межі двох станів - спання та неспання; фактично прямо в робочому кабінеті йому “намарилося” пророцтво всевидячого і всезнаючого шамана, історія зустрічі з яким під час полювання на таємничому Алтаї склала ціле вставне оповідання. У цьому фрагменті знаковими є відповіді шамана на два питання мисливця В. Городецького до духів верхнього і, відповідно, нижнього світів. Якщо трансльовану шаманом відповідь останніх на питання щодо року своєї смерті (1930 р.) герой швидко розшифрував, то відповідь на питання, чи здійснив він те, що йому належало втілити в життя, була більш загадковою. Шаман говорив про страшний недолік створеної архітектором “четвірки кращого” й про необхідність завершити іншу, благодатну четвірку, в якій прихована триєдність світу [Ільченко 2009: 60]. Результатом сонної фантазії стало й швидке прозріння В. Городецького щодо "четвірки кращого": побудовані ним Міський музей (храм мистецтва), костел і кенаса караїмів це три храми, а Будинок з химерами не "вписується" в четвірку кращих його споруд, бо є “антихрамом". Тільки під кінець життя (відповідно, на останніх сторінках роману) будівничому вдалося розгадати слова алтайського шамана про “іншу, благодатну четвірку": це мали бути чотири храми чотирьох конфесій, що репрезентують триєдність Старого Світу, тобто християнство, юдаїзм, іслам. Це мала бути антитеза задумам сил темряви. Намагаючись позбутися візитів “нічного гостя”, зодчий розуміє, що мусить якось допомогти світлу й таким способом отримати спокій. Його зустрічі та розмови 3 дружиною, колегами, київською інтелектуальною елітою описано в романі як пошуки способу боротьби з примарами. Як було згадано, він вирішує грати зі Змієм і перехитрувати, перемогти його. Утім, наратив роману побудований так, що читач переважно спостерігає за вступною частиною гри, тобто за пошуками тієї хитрості, якою можна перемогти Змія. В. Городецький звів православну церкву в Черкасах, римо-католицький костел та юдаїстську кенасу в Києві й мав намір побудувати мечеть у Тегерані, де він прожив останні роки, виконуючи різні замовлення - будівництво вокзалу, готелю, урядових будинків, палацу для шаха. За версією О. Ільченка, архітектор зрештою отримав від шаха дозвіл на зведення мечеті, але не встиг утілити цей задум, оскільки помер саме на поч. 1930 р. Отже, сонна фантазія будівничого про пророцтво шамана, 3 одного боку, має профетичний характер, тобто спрямована в майбутнє як “віща", а з другого - відкриває певне “приховане” теперішнє героя.

У романі використані й профетичні марення В. Городецького під час нападів малярії (поляк стане Папою Римським, турок стрілятиме в Папу), і марення-спогади (сім'я архітектора фактично розпалася, смертельно поранено П. Столипіна під час замаху). Ці оніричні елементи подано як штрихові картини, за принципом монтажу. Марення чергуються зі спалахами свідомості героя, яка важко переживає еміграцію до Польщі, що спричинено наступом більшовиків на Київ та інші території України. Здатність до пророчих візій, 
якою наділено В. Городецького, - свідчення того, що він є ретранслятором вищої волі. О. Ільченко зображає архітектора, який „вів подвійне життя - в духовно-містичному сенсі" [Клименко 2008], який зазирав у темні глибини життя й знаходив потаємні пружини, що рухають світом, який їм корився й протестував проти них, який мав свої здобутки й утрати.

Отже, у творі Micmo з химерами оніризм виконує важливу роль передусім як засіб композиційної побудови та організації розвитку подій. У романі зустрічаються фрагменти снів (більш об'ємними є тільки два “снозаписи”, це сни-потрясіння пролептичного характеру), сонна фантазія (яка містить пророцтво), мінімізовані записи марень (шматки спогадів і пророчих візій як наслідок фізичного й психологічного зламу), а також багато штрихових “повідомлень" про те, що певним героям сняться певні сни (переважно кошмарні). Усе це забезпечує структурну єдність тексту і зв'язність подій, що відбуваються у двох часових зрізах - на поч. ХX ст. і, відповідно, ХХІ ст., підтримує напругу оповіді, хоча автор й обирає техніку своєрідного зчитування снів недієгетичним наратором з (під)свідомості героїв замість більш експресивного "снозапису з перших вуст". Кожен із зазначених оніричних станів — це певний акт містичного досвіду (передусім архітектора В. Городецького), єдиноможливий спосіб проникнення в сутність речей. Оніричні фрагменти тексту сприяють розкриттю прихованого, утаємниченого, виявляються свідченням ще не спізнаних істин. Саме через оніропростір автор розкриває драматичну боротьбу у свідомості головного героя, досліджує позасвідомі впливи на його вчинки та поведінку. Основний оніричний образ роману - Змій, який прагне заволодіти Києвом, позбавити його сакрального статусу, - має архетипну природу. Відтак міф про химерний архітектурний трикутник, у якому опинилася Свята Софія Київська (Сакральне Серце Києва), через що в романі концептуалізовано вплив ірраціонального на урбаністичний простір столиці, видається цікавим зразком індивідуального міфотворення О. Ільченка й гідною уваги дослідників художньою складовою “київського тексту”.

\section{Список використаної літератури}

Бовсунівська Т., Достовірність онірокритики та ї̈ постмодерні стратегії, [в:] „Сучасні літературознавчі студії. Випуск І. Онірична парадигма світової літератури”, 2004, c. $14-22$.

Борцов А. Г., Ассоциация Змея с архетипом Camaны, [в:] Электронный ресурс: https://fil. wikireading.ru/74530 (10.10.2018).

Грищенко О. В., Архітектурна візія Києва в романі „Місто з химерами” О. Ільченка, [в:] „Науковий вісник Миколаївського державного університету імені В. О. Сухомлинського. Серія: Філологічні науки (літературознавство)”, 2014, вип. 4.13 (104), с. 55-61. 
Гроф С., Космическая игра. Исследование рубежей человеческого сознания, Москва: Издво Трансперсонального ин-та, 1997.

Ільченко О., Місто з химерами, Київ: Грані-Т, 2009.

Клименко В., Роман про архітектора з химерами, [в:] Електронний ресурс: https:// umoloda.kyiv.ua/number/1144/164/ (05.10.2018).

Котик І., Геометрія українськоїхимерності (Ільченко О. Місто з химерами), [в:] Критика прози: статті та есеї, Київ: Грані-Т, 2011, с. 114-119.

Поліщук Я., Місто, варте культу, [в:] Його ж, Ревізії пам'яті. Літературна критика, Луцьк: ПДВ „Твердиня”, 2011.

Фенько Н. М., Естетичні функції картин сновидінь у художніх творах украӥнських письменників другої половини XIX-XX століть, автореф. ... канд. філол. наук, Дніпропетровськ 1999.

Шупта-В'язовська О., Художнє сновидіння як тип художнього мислення, [в:] „Сучасні літературознавчі студії. Випуск І. Онірична парадигма світової літератури”, 2004, c. $161-166$.

\section{Spysok vykorystanoi literatury [References]}

Bovsunivska T., Dostovirnist onirokrytyky ta yii postmoderni stratehii [The Reliability of Oneirocriticism and its Postmodern Strategies], [v:] „Suchasni literaturoznavchi studii. Vypusk I. Onirychna paradyhma svitovoi literatury", 2004, s. 14-22.

Bortsov A. G., Associaciya Zmeya s arxetipom Satany [Serpent Association with the Archetype of Satan], [v:] Elektronnyi resurs: https://fil.wikireading.ru/74530 (10.10.2018).

Hryshchenko O. V., Arkhitekturna viziia Kzieva v romani „Misto z khymeramy” O. Ilchenka [Architectural Vision of Kiev in the Novel The City with Chimeras by O. Ilchenko], [v:] „Naukovyi visnyk Mykolaiivskoho deryhavnoho universytetu imeni V. O. Suhomlynskoho. Seriia: Filolohichni nauky (literaturoznavstvo)", 2014, vyp. 4.13 (104), s. 55-61.

Grof S., Kosmicheskaya igra. Issledovanie rubezhei chelovecheskogo soznaniya [Space Game. The Study of the Frontiers of Human Consciousness], Moskva: Izd-vo Transpersonalnogo in-ta, 1997.

Ilchenko O., Misto z khymeramy [The City with Chimeras], Kyiv: Hrani-T, 2009.

Klymenko V., Roman pro arkhitektora $z$ khymeramy [Novel about an Architect with Chimeras], [v:] Elektronnyi resurs: https://umoloda.kyiv.ua/number/1144/164/ (05.10.2018).

Kotyk I., Heometriia ukraiinskoi khymernosti (Ilchenko O. Misto z khymeramy) [The Geometry of Ukrainian Bizarre (Ilchenko O. The City with Chimeras)], [v:] Krytyka prozy: statti ta eseii, Kyiv: Hrani-T, 2011, s. 114-119.

Polishchuk Ia., Misto, varte kultu [City Worthy of Worship], [v:] Yoho zh, Revizii pamiati. Literaturna krytyka, Lutsk: PDV „Tverdznia”, 2011, s. 9-25.

Fenko N. M., Estetychni funktsii kartyn snovydin u hudozhnikh tvorakh ukrainskykh pysmennykiv druhoi polovyny XIX - XX stolit [Aesthetic Functions of Pictures of Dreams in the Works of 
Ukrainian Writers of the Second Half of the 19th and 20th Centuries], avtoref. ... kand. filol. nauk, Dnipropetrovsk 1999.

Shupta-Viazovska O., Khudozhnie snovydinnia yaktyp khudozhnogo myslennia [Artistic Dreams as a Type of Artistic Thinking], [v:] ,Suchasni literaturoznavchi studii. Vypusk I. Onirychna paradyhma svitovoi literatury", 2004, s. 161-166. 